\title{
Correlation and Path Analysis for Different Characteristics in Germplasm of Moth Bean [Vigna aconitifolia (Jacq.) Marechal]
}

\author{
S.N. Kohakade ${ }^{1}$, V.V. Bhavsar ${ }^{1^{*}}$ and V.Y. Pawar $^{2}$ \\ ${ }^{1}$ Department of Agricultural Botany, College of Agriculture, Dhule (MS), India \\ ${ }^{2}$ Bajra Research Scheme, College of Agriculture, Dhule (MS), India \\ *Corresponding author
}

\section{A B S T R A C T}

\begin{tabular}{|c|}
\hline Keywords \\
\hline $\begin{array}{l}\text { Correlation } \\
\text { coefficient, Path } \\
\text { analysis, Germplasms, } \\
\text { Moth bean [Vigna } \\
\text { aconitifolia (Jacq.) } \\
\text { Marechal]. }\end{array}$ \\
\hline Article Info \\
\hline $\begin{array}{l}\text { Accepted: } \\
\text { 17 September } 2017 \\
\text { Available Online: } \\
10 \text { November } 2017\end{array}$ \\
\hline
\end{tabular}

The Present investigation entitled 'Correlation and path analysis for different characteristics in germplasms of moth bean' [Vigna aconitifolia (Jacq.) Marechal] was undertaken during Kharif 2016. The experiment was carried out in Randomized block Design (RBD) with three replications to derive Correlation coefficient and Direct and Indirect effects in 44 germplasms in Moth bean. In 44 genotypes it has been revealed that, number of pods per plant, number of cluster per plant, number of pods per cluster, number of seeds per pod and 100 seed weight were good indicators of seed yield per plant and can be used for making direct selection for yield. The seed yield per plant was positively and significantly correlated with number of pods per plant, number of cluster per plant, number of pods per cluster, number of seeds per pod, 100 seed weight, number of primary branches. The high magnitude of direct effect of number of pods per plant, number of primary branches, number of cluster per plant, number of pods per cluster and number of seeds per pod along with highly significant correlation in the desirable direction towards seed yield per plant indicated the true and perfect relationship between seed yield and these characters suggesting direct selection based on these character would help in selecting the high yielding genotypes in moth bean.

\section{Introduction}

Moth bean [Vigna aconitifolia (Jacq) Marechal] belongs to family: Leguminosae /Fabaceae, sub family: Papilionaceae. It is a self-pollinated diploid $(2 \mathrm{n}=2)$ crop. Popularly, it is also known as 'Mat', 'Matki' and 'Moth bean' in different regions. Plant is an annual with spreading prostrate habit forming a mat like cover on soil, hence its name as a mat or moth bean. Canopy of moth bean covers surface area which conserves moisture and protects the soil from erosion. Moth bean is mainly used as "Dal" and some other preparations. Green pods are used as vegetables. It can also be used as green fodder for animals.

It is an important crop of dry and semi-arid areas of India and some countries of Asia. Among Kharif pulses, it has maximum capacity to resist drought condition. It is an excellent source of high quality protein $(23.6 \%)$ in the diet of low income group in developing countries. Moth bean is cultivated for food as well as forage. In extremely low rainfall areas, it is grown alone as pure crop, while, in areas receiving adequate rains it may 
be grown as intercrop with pearl millet, sorghum, cotton, green gram or some other fodder grasses. India has major area under moth bean cultivated in world. It is also grown in Pakistan, Shrilanka, China, and United States of America (USA). In India moth bean is mainly grown in Rajasthan which contribute about $75 \%$ of total area and production of the country. Other important states for cultivation of moth bean are Maharashtra, Gujarat, Jammu \& Kashmir and Punjab.

Correlation studies provide knowledge of association among different characters and grain yield. The study of association among various traits is useful for breeders in selecting genotypes possessing groups of desired traits. The correlation coefficients become insufficient for using yield components as selection criteria to improve grain yields. It is reasonable to know whether any yield components has a direct or indirect effect on grain yield, so that selection studies can be carried out successfully.

Correlated response: Two characters say $x$ and $y$, are correlated. A change in the mean of $x$ through selection will cause an associated change in the mean of $y$ also. This change in $y$ brought about through indirect selection on an associated character $x$ is known as correlated response (Singh and Chaudhary, 1977).

The path coefficient analysis provides a more realistic picture of the relationship as it considers direct as well as indirect effects of the variables by partitioning the correlation coefficients.

Correlation and path analysis estimates between yield and other characters are useful in selecting desired plant type in designing an effective breeding programme. When change in one variable causes the change on other variable, the variables are said to be correlated. Keeping the above facts a view, the present investigation entitled "Correlation and path analysis for different characteristics in germplasm of moth bean' [Vigna aconitifolia (Jacq.) Marechal]" was proposed to gather information on the following objectives:

To better insight into the cause and effect relationship between pairs of characters, study of correlation in conjunction with path analysis is essential.

\section{Materials and Methods}

The experimental materials consisting forty four germplasm of moth bean collected from Solapur, Ahmednagar, Pune, Dhule and Nandurbar districts of Maharashtra. The experiment was laid out in RBD with three replications at Department of Botany, College of Agriculture, Dhule (M.S.) during Kharif 2016. By adopting a spacing of $30 \mathrm{~cm}$ between rows and $10 \mathrm{~cm}$ between plants respectively, at recommended package of practices were followed to raise good and healthy crop stand. Data were collected on eleven yield and yield contributing characters $v i z$. days to $50 \%$ flowering, days to maturity, length of main axis, number of primary branches, number of cluster per plant, number of pods per cluster, number of pods per plant, pod length, seeds per pod, 100 seed weight, seed yield per plant.

The mean of five plants was subjected to statistical analysis. The data for different characters were statistically analyzed for significance by using analysis of variance technique described by Panse and Sukhatme (1985).The adapted design was Randomized Block Design (RBD) with three replications. The significance of mean sum of square for each character was tested against the corresponding error degrees of freedom using "F" Test (Fisher and Yates, 1967). 
Correlation between eleven characters was estimated according to the method given by Singh and Chaudhary (1977). Direct and indirect effects were estimated as described by Dewey and Lu (1959). Statistical analysis was done by using WINDOSTAT program.

\section{Results and Discussion}

Analysis of variance revealed significant differences among genotypes for all the characters (Table 1).

Analysis of variance for ten characters indicated that the genotypes used in the present studies were significantly different. The correlation coefficients at both genotypic and phenotypic levels estimated between grain yields per plant with all other characters are presented in Table 2 and 3 respectively. In the present investigation, the genotypic correlation coefficients were higher than the phenotypic correlation coefficients as observed by Johnson et al., (1955). This might have occurred due to genes governing two traits were similar and the environmental conditions pertaining to the expression of these traits might have small and similar effects.

Seed yield exhibited highly significant positive correlation with all other characters except pod length suggesting dependency of yield on these characters (Table 2 and 3 ). The highest association of yield was with number of pods per plant (0.976) followed by number of primary branches (0.915), number of cluster per plant (0.870), number of pods per cluster (0.851), days to maturity (0.722), days to 50 per cent flowering (0.719), number of seeds per pod (0.621), length of main axis (0.528), 100 seed weight (0.508). But, it showed non-significant negative correlation with pod length (-0.026). These results are in accordance with the findings of Jat et al., (1984); Bhavsar and Birari (1989); Kakani et al., (2003); Patil et al., (2007); Bangar et al., (2008) and Babbar et al., (2012).

Table.1 Analysis of variance for different characters in moth Bean

\begin{tabular}{|c|l|c|c|c|}
\hline \multirow{2}{*}{$\begin{array}{c}\text { Sr. } \\
\text { No }\end{array}$} & \multicolumn{1}{|c|}{ Characters } & \multicolumn{2}{c|}{ Mean sum of square } \\
\cline { 3 - 5 } & & Replication & Genotype & Error \\
\hline 1 & Days to 50\% flowering & 1.96 & $1464.9^{* *}$ & 2.82 \\
\hline 2 & Days to maturity & 2.550 & $1273.26^{* *}$ & 6.67 \\
\hline 3 & Length of main axis (cm) & 9.490 & $9951.60^{* *}$ & 35.49 \\
\hline 4 & Number of primary branches & 0.12 & $7.67 * *$ & 0.19 \\
\hline 5 & Number of cluster per plant & 0.034 & $419.32^{* *}$ & 11.29 \\
\hline 6 & Number of pods per cluster & 0.037 & $0.52^{* *}$ & 0.02 \\
\hline 7 & Number of pods per plant & 1.330 & $3303.82^{* *}$ & 45.99 \\
\hline 8 & Pod length (cm) & 0.011 & $0.108^{* *}$ & 0.032 \\
\hline 9 & Number of seeds per pod & 0.062 & $2.988^{* *}$ & 0.139 \\
\hline 10 & 100 seed weight (g) & 0.011 & $0.290^{* *}$ & 0.010 \\
\hline 11 & Grain yield per plant (g) & 0.016 & $65.177^{* *}$ & 0.957 \\
\hline
\end{tabular}

$*, * *$ Indicates significance at 5\% and $1 \%$ level, respectively. 
Table. 2 Genotypic correlation coefficient for eleven characters in moth bean

\begin{tabular}{|c|c|c|c|c|c|c|c|c|c|c|c|c|}
\hline & Characters & 1 & 2 & 3 & 4 & 5 & 6 & 7 & 8 & 9 & 10 & 11 \\
\hline 1. & Days to $50 \%$ flowering & 1.000 & $0.991 * *$ & $0.961 * *$ & $0.759 * *$ & $0.786 * *$ & $0.765 * *$ & $0.789 * *$ & $-0.463 * *$ & $0.937 * *$ & $0.353^{* *}$ & $0.719 * *$ \\
\hline 2. & Days to maturity & & 1.000 & $0.953 * *$ & $0.766 * *$ & $0.796 * *$ & $0.755^{* *}$ & $0.795 * *$ & $-0.453 * *$ & $0.932 * *$ & $0.334 * *$ & $0.722 * *$ \\
\hline 3. & Length of main axis $(\mathrm{cm})$ & & & 1.000 & $0.594 * *$ & $0.662 * *$ & $0.603 * *$ & $0.617 * *$ & $-0.606^{* *}$ & $0.926^{* *}$ & $0.210 *$ & $0.526 * *$ \\
\hline 4. & No. of primary branches & & & & 1.000 & $0.914 * *$ & $0.440 * *$ & $0.940 * *$ & $0.512 * *$ & $0.852 * *$ & $0.2474 * *$ & $0.915 * *$ \\
\hline 5. & No. of cluster per plant & & & & & 1.000 & $0.645 * *$ & $0.926 * *$ & -0.111 & $0.716^{* *}$ & $0.339 * *$ & $0.870 * *$ \\
\hline 6. & No. of pods per cluster & & & & & & 1.000 & $0.876^{* *}$ & $-0.213^{* *}$ & $0.604 * *$ & $0.492 * *$ & $0.851 * *$ \\
\hline 7. & No. of pods per plant & & & & & & & 1.000 & -0.124 & $0.668 * *$ & $0.453 * *$ & $0.976^{* *}$ \\
\hline 8. & Pod length $(\mathrm{cm})$ & & & & & & & & 1.000 & $-0.391 * *$ & 0.059 & -0.026 \\
\hline 9. & No. of seeds per pod & & & & & & & & & 1.000 & $0.278 * *$ & $0.621 * *$ \\
\hline 10. & 100 seed weight $(\mathrm{g})$ & & & & & & & & & & 1.000 & $0.508 * *$ \\
\hline 11. & Grain yield per plant (g) & & & & & & & & & & & 1.000 \\
\hline
\end{tabular}

$*, * *$ Indicates significance at 5\% and $1 \%$ level, respectively.

Table.3 Phenotypic correlation coefficient for eleven characters in moth bean

\begin{tabular}{|c|c|c|c|c|c|c|c|c|c|c|c|c|}
\hline & Characters & 1 & 2 & 3 & 4 & 5 & 6 & 7 & 8 & 9 & 10 & 11 \\
\hline 1 & Days to $50 \%$ flowering & 1.000 & $0.987 * *$ & $0.953 * *$ & $0.219 *$ & $0.754 * *$ & $0.714 * *$ & $0.771 * *$ & $-0.316 * *$ & $0.875^{* *}$ & $0.332 * *$ & $0.701 * *$ \\
\hline 2 & Days to maturity & & 1.000 & $0.941 * *$ & $0.219^{*}$ & $0.761 * *$ & $0.705^{* *}$ & $0.774 * *$ & $-0.305 * *$ & $0.864 * *$ & $0.312 * *$ & $0.705^{* *}$ \\
\hline 4 & No. of primary branches & & & & 1.000 & $0.330 * *$ & 0.110 & $0.256 * *$ & 0.044 & $0.202 *$ & 0.043 & $0.195^{*}$ \\
\hline 5 & No. of cluster per plant & & & & & 1.000 & $0.614 * *$ & $0.915 * *$ & -0.012 & $0.667 * *$ & $0.329 * *$ & $0.859 * *$ \\
\hline 6 & No. of pods per cluster & & & & & & 1.000 & $0.831 * *$ & -0.088 & $0.577 * *$ & $0.458 * *$ & $0.809 * *$ \\
\hline 7 & No. of pods per plant & & & & & & & 1.000 & -0.032 & $0.635 * *$ & $0.434 * *$ & $0.968 * *$ \\
\hline 8 & Pod length $(\mathrm{cm})$ & & & & & & & & 1.000 & -0.056 & 0.040 & 0.031 \\
\hline 9 & No. of seeds per pod & & & & & & & & & 1.000 & $0.247 * *$ & $0.591 * *$ \\
\hline 10 & 100 seed weight $(\mathrm{g})$ & & & & & & & & & & 1.000 & $0.487 * *$ \\
\hline 11 & Grain yield per plant (g) & & & & & & & & & & & 1.000 \\
\hline
\end{tabular}

$*$, ** Indicates significance at 5\% and $1 \%$ level, respectively. 
Table.4 Genotypic path coefficient for ten characters in sesamum

\begin{tabular}{|c|c|c|c|c|c|c|c|c|c|c|c|c|}
\hline & Characters & 1 & 2 & 3 & 4 & 5 & 6 & 7 & 8 & 9 & 10 & 11 \\
\hline 1 & Days to $50 \%$ flowering & -1.878 & -1.862 & -1.806 & -1.425 & -1.477 & -1.437 & -1.482 & 0.8711 & -1.761 & -0.663 & $0.719 * *$ \\
\hline 2 & Days to maturity & 0.820 & $\mathbf{0 . 8 2 7}$ & 0.789 & 0.634 & 0.659 & 0.625 & 0.658 & -0.375 & 0.771 & 0.276 & $0.727 * *$ \\
\hline 3 & Length of main axis $(\mathrm{cm})$ & -0.524 & -0.520 & -0.545 & -0.324 & -0.361 & -0.329 & -0.336 & 0.3306 & -0.505 & -0.114 & $0.526 * *$ \\
\hline 4 & No. of primary branches & 0.120 & 0.121 & 0.094 & 0.159 & 0.206 & 0.070 & 0.149 & 0.0814 & 0.135 & 0.039 & $0.915 * *$ \\
\hline 5 & No. of cluster per plant & 1.520 & 1.539 & 1.280 & 2.514 & 1.931 & 1.247 & 1.790 & -0.216 & 1.384 & 0.666 & $0.870 * *$ \\
\hline 6 & No. of pods per cluster & 1.463 & 1.444 & 1.154 & 0.842 & 1.234 & 1.916 & 1.675 & -0.408 & 1.156 & 0.941 & $0.851 * *$ \\
\hline 7 & No. of pods per plant & -1.555 & -1.567 & -1.215 & -1.851 & -1.825 & -1.725 & -1.969 & 0.2451 & -1.315 & -0.893 & $0.976 * *$ \\
\hline 8 & Pod length $(\mathrm{cm})$ & 0.152 & 0.149 & 0.199 & -0.168 & 0.036 & 0.070 & 0.041 & -0.329 & 0.129 & -0.019 & -0.026 \\
\hline 9 & No. of seeds per pod & 0.557 & 0.553 & 0.550 & 0.506 & 0.425 & 0.359 & 0.396 & -0.233 & 0.593 & 0.165 & $0.621 * *$ \\
\hline 10 & 100 seed weight $(\mathrm{g})$ & 0.042 & 0.040 & 0.025 & 0.029 & 0.040 & 0.059 & 0.054 & 0.0072 & 0.033 & 0.119 & $0.508 * *$ \\
\hline
\end{tabular}

Table.5 Phenotypic path coefficient for ten characters in sesamum

\begin{tabular}{|c|c|c|c|c|c|c|c|c|c|c|c|c|}
\hline & Characters & $\mathbf{1}$ & 2 & 3 & 4 & 5 & 6 & 7 & 8 & 9 & 10 & 11 \\
\hline 1 & Days to $50 \%$ flowering & 0.047 & 0.046 & 0.044 & 0.010 & 0.035 & 0.033 & 0.036 & -0.014 & 0.041 & 0.015 & $0.701 * *$ \\
\hline 2 & Days to maturity & 0.073 & 0.074 & 0.069 & 0.016 & 0.056 & 0.052 & 0.057 & -0.022 & 0.064 & 0.023 & $0.705 * *$ \\
\hline 3 & Length of main axis $(\mathrm{cm})$ & -0.242 & -0.239 & -0.254 & -0.040 & -0.160 & -0.141 & -0.152 & 0.102 & -0.217 & -0.049 & $0.509 * *$ \\
\hline 4 & No. of primary branches & -0.011 & -0.011 & -0.008 & -0.051 & -0.016 & -0.005 & -0.013 & -0.002 & -0.010 & -0.002 & $0.195 *$ \\
\hline 5 & No. of cluster per plant & -0.143 & -0.144 & -0.119 & -0.062 & -0.189 & -0.116 & -0.173 & 0.002 & -0.126 & -0.062 & $0.859 * *$ \\
\hline 6 & No. of pods per cluster & -0.080 & -0.079 & -0.062 & -0.012 & -0.069 & -0.112 & -0.093 & 0.010 & -0.065 & -0.051 & $0.809 * *$ \\
\hline 7 & No. of pods per plant & 0.924 & 0.928 & 0.716 & 0.307 & 1.096 & 0.996 & 1.198 & -0.039 & 0.761 & 0.520 & $0.968 * *$ \\
\hline 8 & Pod length $(\mathrm{cm})$ & 0.0001 & 0.0001 & 0.0002 & 0.000 & 0.000 & 0.000 & 0.000 & -0.0004 & 0.000 & 0.000 & 0.031 \\
\hline 9 & No. of seeds per pod & 0.113 & 0.111 & 0.110 & 0.026 & 0.086 & 0.074 & 0.082 & -0.007 & 0.129 & 0.032 & $0.591 * *$ \\
\hline 10 & 100 seed weight $(\mathrm{g})$ & 0.020 & 0.019 & 0.011 & 0.002 & 0.020 & 0.028 & 0.026 & 0.002 & 0.015 & 0.061 & $0.487 * *$ \\
\hline
\end{tabular}

Residual effect $=(0.202)$ Bold value, indicated direct effect

$*, * *$ Indicates significance at $5 \%$ and $1 \%$ level, respectively. 
The path coefficients at both genotypic and phenotypic levels estimated between grain yield per plant and yield contributing characters was carried out by using correlation coefficient.

The results obtained are presented in Table 3 and 4, respectively. The characters which emerged as the major component of seed yield per plant in path coefficient analysis (Table 4 and 5) was exerted by, number of cluster per plant followed by number of pods per cluster, days to maturity and number of seeds per pod which had highest direct effects on seed yield per plant at both genotypic level. At phenotypic level number of pods per plant recorded maximum direct effect on seed yield per plant. This is in accordance with the findings of Naidu et al., (1986); Garg et al., (2003); Kakani et al., (2003); Bangar et al., (2008).

In general, correlation and path analysis carried concluded that the number of pods per plant, number of cluster per plant and number of pods per cluster influenced the seed yield more than any of the other characters. Hence, it would be worthwhile to lay more emphasis on these characters in selection programme to improve the grain yield in sesame.

\section{References}

Babbar, A., V. Prakash, P. Tiwari and M. A. Iquebal. 2012.Genetic variability for chickpea under late sown season. Legume Res., 35 (1):1-7.

Bangar, N. D., Amita Lakra and B. H. Chavan. 2008. Correlation and Path Coefficient Analysis in Moth bean. J Maharashtra agric. Univ., 33(2):164-166

Bhavsar, V. V. and S. P. Birari. 1989. Variability, correlation and path analysis in moth bean. J. Maharashtra agric. Univ., 14(2):148150.

Dewey, D. R. and K. H. Lu. 1959. A correlation and path analysis of components of crested wheat grass seed production. Agron. J., 51: 513-518.

Fisher, R.A. and Yates. 1967. Statistical Tables for Biological Agricultural and Medical Research Oliver and Boyd, Edington.

Garg D. K., R. K. Kakani, R. C. Sharma and P. C. Gupta. 2003. Genetic variability and character association in moth bean under hyper Arid Region, Agriculture Research Station Bikaner. Advances Arid Legumes Res., pp. 93-97.

Jat, P. M. 1984. Association analysis and genetic divergence in moth bean. M. Sc. (Agri.) Thesis, Univ. of Udaipur, Rajasthan.

Johnson, H.W., H. F. Robinson and R. E. Comstock 1955. Genotypic and phenotypic correlation in soybean and their implication in selection. Agron. J. 47: 477-483.

Kakani, R. K., R. C. Sharma and D. K. Garg. 2003. Genetic Divergence, variability and character association in moth bean. Advances Arid Legumes Res., pp. 98-103.

Naidu M.R.; S. Singh and R. Bakshi. 1986. Variability and path coefficient analysis of yield components in moth bean (Vigna aconitifolia Jacq.). Haryana Agril. Univ. J. Res., 16(2): 168-171.

Patil S. C., V. P. Patil, H. E. Patil and S. V. Pawar. 2007. Correlation and path coefficient studies in moth bean. Internal. $J$. Plant Sci., 2 (2): 141-144.

Singh R. K. and B. D. Choudhary. 1977. "Biometrical methods in quantitative genetic analysis." Kalyani publication, New Delhi, pp.39-68.

\section{How to cite this article:}

Kohakade, S.N., V.V. Bhavsar and Pawar, V.Y. 2017. Correlation and Path Analysis for Different Characteristics in Germplasm of Moth Bean [Vigna aconitifolia (Jacq.) Marechal]. Int.J.Curr.Microbiol.App.Sci. 6(11): 2181-2186. doi: https://doi.org/10.20546/ijcmas.2017.611.257 